\title{
Overview of Country Experience in Land Rights and Developmental Statehood: South Korea, Taiwan, China and Singapore
}

\begin{abstract}
This article examines lessons that can be drawn from the land rights regimes of four countries that have commendable economic performance. It highlights the nature of land rights during the developmental statehood pursuits of three East Asian states (South Korea, Taiwan and Singapore) and a country that currently pursues socialist market economic policy, i.e. China. The themes that are considered include (a) lessons from the land rights regime in South Korea including the salient features of developmental states, (b) Taiwan's land reform during the early 1950s and land requisition for industrial use, (c) China's land rights regime and administrative laws, and (d) land rights in Singapore and entrepreneur perceptions about its institutions. These countries are chosen due to their relevance to the Ethiopian land law regime. The article highlights how South Korea and Taiwan carried out effective land reform by redistributing private land rights without resorting to nationalization. It is argued that neither the notion of state ownership of land as practised in Singapore nor current improvements in the scope of Chinese land use rights explain the denial of economic value to land use rights.
\end{abstract}

Elias N. Stebek *

\section{Key words}

Land use rights, developmental state, land reform, property rights.

DOI http://dx.doi.org/10.4314/mlr.v7i2.2

\section{Introduction}

Since 1975, Ethiopia's land laws have pursued an ideological path that was significantly influenced by the Soviet Union and China. Land is still publicly owned in Ethiopia despite the post-1991 shift toward the privatization of various

* LL.B, LL.M, PhD; Associate Professor, St. Mary’s University, School of Graduate Studies. Email: elstebek@gmail.com, eliasnr@smuc.edu.et

This article is a revised and expanded version of the fourth chapter of the research titled "Property Rights Protection and Private Sector Development in Ethiopia" which was submitted to the Private Sector Development Hub at the Ethiopian Chamber of Commerce and Sectoral Associations. The author is grateful to the Private Sector Development Hub for sponsoring the research in partnership with SIDA (Swedish International Development Cooperation Agency). 
publicly owned enterprises and the policy declaration of market-based economic policy. The Ethiopian government currently pledges to pursue the economic policies of a democratic developmental state.

Country experience from selected countries can thus be relevant. The experiences of South Korea and Taiwan are relevant because the path they have undergone as developmental states until the 1970s and 1980s can inform the pursuits of countries who are in the course of espousing the path. The current land reform pursuits in China are relevant because they indicate the changes that are being made in a country that has not yet disclaimed (the Marxist version of) socialism, but still considers its economic system as socialist, with Chinese characteristics. Even if Singapore is a city state which is drastically different from countries like Ethiopia, the economic value given to land use rights in the context of public ownership of land renders its experience relevant to Ethiopia.

\section{Features of Developmental States: The South Korean Experience}

\subsection{Salient features of developmental states}

The policy setting of developmental statehood in South Korea (highlighted in this section) informs the discussion on land rights (in Section 2) that prevailed during the 1960s and 1970s. These decades mark the initial years of economic take-off for South Korea, after which the country's legal regime progressively marched onto a path of lesser state involvement. A brief discussion of the features of developmental states (with South Korea as an example) ${ }^{1}$ is meant to offer an overview of the policy framework in which land rights were formulated in South Korea during its land reform of the 1960s and thereafter.

The overall property rights index of developmental states shows that they rank higher than other Asian States. Hong Kong, Singapore, Japan, South Korea and Taiwan rank as the highest in comparison to all countries in Asia. ${ }^{2}$ The scores are 90 each for Hong Kong and Singapore, 80 for Japan and 70 each for South Korea and Taiwan. A developmental state goes extra miles (beyond day to day state functions) and involves itself in pursuits of creating conducive conditions for the development and economic performance of the private sector. What characterizes a developmental state does not relate to restrictions it imposes on private property rights, but its level of state intervention in

\footnotetext{
${ }^{1}$ The scope of this article does not allow an elaborate discussion on the path undergone by all East Asian developmental states during their economic take-offs.

$2<$ http://www.globalpropertyguide.com/Asia/South-Korea/property-rights-index $>$, accessed: 03 August 2013.
} 
empowering and supporting economic actors while at the same time retaining its autonomy from rent-seeking individuals and companies among economic actors.

The mainstream argument in favour of the non-interventionist minimal state and the need for wider space for market mechanisms is the following:

As states expand their size, their range of functions, and the amount of resources they control, the proportion of economic activity that becomes incorporated into rental havens will increase correspondingly, and economic efficiency and dynamism will decline. Conversely, to the degree that the economic power and prerogatives of the state can be curtailed, prospects for growth, efficiency, and welfare will be enhanced. Therefore, the sphere of state action should be reduced to the minimum, and bureaucratic control should be replaced by market mechanisms wherever possible. ${ }^{3}$

This, however, assumes the existence of the conditions for the effective operation of what Adam Smith regarded as the 'invisible hand' ${ }^{4}$ of market mechanisms that operate in the interest of the common good while everyone pursues his/her self-interest. The caveat in this regard is the need to consider the two assumptions of being informed and being rational that are inherent in Adam Smith's notion of utmost freedom of exchange based on self-interest. Smith envisaged "rational choice" that presupposes informed self-interest and rational decisions that give due respect to the legitimate interest of others.

... [A]ccording to Smith, men do not always act in their own interest. They can be mistaken about what it is (as when they are not as thrifty as they should be). When they know their interest they can be mistaken about what will best serve it (as when they overestimate the chance of success in an occupation). Or they may not consult their interest at all (as when the pursuit of pleasure drives them to ruin). ${ }^{5}$

Free market envisages exchange of goods/services which presumes the capability, opportunity and access for individuals, legal persons and economic systems to produce the goods and the services to be marketed. In other words, the one on the buying end should also be able to produce and sell goods and/or

${ }^{3}$ Peter B. Evans (1989), "Predatory, Developmental, and Other Apparatuses: A Comparative Political Economy Perspective on the Third World State", Sociological Forum, Vol. 4, No. 4, p. 564.

4 "In the Wealth of Nations, Smith writes of an invisible hand in the course of describing a particular condition that may or may not be present in a transaction on a competitive market. The condition is that in which a man who intends to benefit only himself in a particular way may, in the act of procuring that benefit, produce a benefit of a different kind for everyone including himself." William D. Grampp (2000), "What Did Smith Mean by the Invisible Hand?" Journal of Political Economy, Vol. 108, No. 3 (The University of Chicago Press, June 2000), p. 443.

${ }^{5}$ Id., p. 444 [citing (Wealth of Nations, pp. 346, 123, 907)] 
services commensurate with what he/she/it buys. This seems to assume a setting whereby economic actors operate in a subjective state of competence and responsibility plus the social and global trading environment which does not offer free ride to certain hegemonic economic actors.

Although the notion of the developmental state is relatively recent, there have been states that pursued policies beyond the minimal state functions of maintaining peace, security and national defence. There was state intervention to facilitate the take-off phases of economic systems, and this includes countries such as Germany and USA during their kick-start phases of industrialization. This was advocated by Freidrich List (1789-1846), who, inter alia, addressed the issue of delayed (catch-up) development due to which 'a less productive economy' is 'confronted by a more productive one'. ${ }^{6}$ List supported state involvement in protecting infant industries because products from countries with low levels of competitiveness will lose in the competition. ${ }^{7}$ The extent to which the role of the state has diminished under the current realities of globalization has been subject to academic discourse. ${ }^{8}$

The notion of the developmental state is capitalist but still different from laissez-faire capitalism; It is also different from market socialism (such as the Chinese model of development) and soviet type command economies. ${ }^{9}$ Yu-Shan $\mathrm{Yu}$ notes the features of property rights in laissez faire capitalism (private ownership and private control), state capitalism (private ownership and state control) and command economy (state ownership and state control), ${ }^{10}$ and analyzes the Chinese economic reforms in comparison with these three economic systems. Chinese economic reforms did not (unlike capitalist developmental states such as Japan, Taiwan and the others) embrace private ownership as the mainstream property rights regime, and did not also cling onto the traditional soviet-model command economy. It rather allowed cohabitation of the private sector with the dominant public sector, and in particular, allowed market economy (blended with some regulation) to be at the wheels

\footnotetext{
${ }^{6}$ Dieter Senghaas (1991), 'Freidrich List and the Basic Problems of Modern Development', Review (Fernand Braudel Center), Vol. 14, No. 3 (Summer, 1991), pp. 451-452.

${ }^{7}$ Ibid.

${ }^{8}$ For an elaborate discussion against the assertions concerning 'the diminishing role of the state', see for example, David Levi-Faur (1997), 'Friedrich List and the Political Economy of the Nation State', Review of International Political Economy, 4:1. Spring 1997, 154-178.

${ }^{9}$ See for example, Yu-Shan Wu (1994), Comparative Economic Transformations, Mainland China, Hungary, the Soviet Union and Taiwan (Stanford University Press,).

${ }^{10}$ Ibid, p. viii.
} 
accompanied by managerial autonomy of State Owned Enterprises (SOEs), particularly where they face demand unpredictability and market competition. ${ }^{11}$

With regard to the core features of developmental states, Chalmers Johnson argues that "the post-war Japanese economic 'miracle' should go primarily to conscious and consistent government policies dating from at least the $1920 \mathrm{~s}$ "12 and he explains the economic, political and social settings in which the Japanese model of development emerged and progressed. Yet he contests overgeneralizations of economic achievements out of context and underlines that "any social science ... must deal with both the gereralizable and the particular, without ruling one or the other out of the court". ${ }^{13}$ Johnson notes that the developmental state is "determined to influence the direction and pace of economic development by directly intervening in the development process, rather than relying on the uncoordinated influence of market forces to allocate economic resources". ${ }^{14}$ In the course of the state's intervention in the development process, he notes the balance of power that exists between the state and economic actors:

When the developmental state is working well, neither the state officials nor the civilian enterprise managers prevail over the other. The state is a 'catalyst' agency, in Michael Lands sense of the term, and the managers are responding to the incentives and disincentives that the state establishes. ${ }^{15}$ This is not an easy combination to put together, but when it is done properly, it can produce miracles of economic development. ${ }^{16}$

The capitalist developmental state is interventionist because it assumes wider roles and actively involves itself in creating an enabling environment for economic actors. On the other hand, the developmental state does not control the economy through central planning and state ownership of the means of production because it does not substitute nor dominate economic actors who are at the wheels of ownership of the means of production.

${ }^{11}$ For the factors that can potentially determine the degree of managerial autonomy of State Owned Enterprises in China, see, for example, S. Loukas et al (1993), 'Managerial Autonomy of State-Owned Enterprises: Determining Factors', Organization Science 4(4), November 1993, pp. 645 - 666.

${ }^{12}$ Chalmers Johnson (1999), 'The Developmental State: Odyssey of a Concept', in The Developmental State, edited by Meredith Woo-Cummings (Cornell University Press), p. 34.

${ }^{13}$ Id., p. 43.

14 See Johnson, Chalmers (1982), MITI and the Japanese Miracle: The Growth of Industry Policy 1925- 1975, (Stanford: Stanford University Press).

${ }^{15}$ Michael Land. 'The Catalyst State', National Interest, Spring 1992, pp. 5-12 [in Johnson supra note 12, p. 60).

${ }^{16}$ Johnson supra note 12, p. 60. 
Instead, developmental states assume a significant role in the economic life of the society through policies, strategic planning and decisions in contrast to the non-interventionist thin (police) state that allows very wide roles to local, regional and global market forces. Invariably, developmental states pursue the capitalist mode of production, but strive to have political, financial, structural and administrative policy space and influence in the process. The tasks of developmental states go beyond regulatory functions and include activities that are necessary for economic transformation. ${ }^{17}$

States, according to Evans, may be developmental or predatory depending upon "the way in which they affect development". ${ }^{18}$ Developmental states "foster long-term entrepreneurial perspectives among private elites by increasing incentives to engage in transformative investments and lowering the risks involved in such investments", and as a result they promote transformation and development. ${ }^{19}$ As Amsden notes, "the two major features of a developmental state are the capacity "to discipline big business, and thereby to dispense subsidies to big business according to a more effective set of allocative principles". ${ }^{20}$

Evans makes a distinction between developmental states and 'predatory' states and he states that in the latter case, "[t]hose who control the state apparatus seem to plunder without any more regard for the welfare of the citizenry than a predator has for the welfare of its prey." According to Evans, the East Asian Newly Industrialized Countries (NICs) are examples of a developmental state, while countries such as Zaire [of the late 1980s] illustrate what he considers as the "predatory state" and Brazil [of the late 1980s] as the 'intermediary' case. ${ }^{21}$

Vartiainen, [identifies] three salient features of a successful developmental state. ... . Primarily, the developmental state must be strong to impose its collective developmental objectives, be meritocratic and ought to be "insulated from both the market and the logic of individual utility maximization". Secondly, the state should have "thick external ties [embeddedness] to the economy's organized agents such as corporations, industrialists, associations and trade unions." And thirdly, there must be "a relationship of mutual dependence or mutual balance between the state and

${ }^{17}$ Elias N. Stebek, Mizan Law Review, Vol. 6. No. 2 [Citing Peter B. Evans (1989), 'Predatory, Developmental and other Apparatuses: A Comparative Political Economy Perspective on the Third World State," Sociological Forum, Vol. 4, No. 4, p. 562.

${ }^{18}$ Ibid.

${ }^{19}$ Id., pp. 562, 563.

${ }^{20}$ A. H. Amsden (1989), Asia's Next Grant,: South Korea and Late Industrialization, New York: Oxford University Press, p. 144.

${ }^{21}$ Evans p. 563, in Stebek, supra note 17. 
the rest of the economy" in such a manner that the state can be "able to 'discipline' economic actors such as firms and trade unions, while appreciating that their privileged positions ultimately depend on the success of the economy". ${ }^{22}$

The core salient features of the developmental state can thus be summarized as: first, active involvement in creating enabling conditions to economic actors by enhancing opportunities and lowering risks, second, institutional capabilities based on meritocracy (which relates to both competence and integrity) and thirdly, embedded autonomy which requires close collaboration and disciplining initiatives in its relationship with 'the economy's organized agents' by at the same time retaining its autonomy from the opportunistic benefits that the relationship may, at times, create.

The purpose and features of interventions by developmental and predatory states are thus drastically different. While a developmental state "empowers and monitors economic actors" and uses strong "meritocratic institutions that monitor economic actors towards the country's developmental strategic objectives", predatory states "are not only corrupt but also make use of coercive institutions that scare economic actors and intimidate entrepreneurs in the guise of regulatory intervention". ${ }^{23}$

There are criticisms regarding the various aspects of authoritarianism in developmental states as observed in Asian countries. The current discourse on developmental states, in effect, uses the qualifier 'democratic'. This concept is in the course of being expressed as a policy orientation in various African countries including Ethiopia, a task which involves various commitments, challenges and opportunities.

The Economic Commission for Africa (in its 2011 Report) defines the developmental state as:

"one that has the capacity to deploy its authority, credibility and legitimacy in a binding manner to design and implement development policies and programmes for promoting transformation and growth, as well as for expanding human capabilities. Such a state takes as its overall socioeconomic goals the long-term growth and structural transformation of the economy, with equity". ${ }^{4}$

${ }^{22}$ Stebek, supra note 17, p. 328; Citing Juhana Vartiainen, “The Economics of Successful State Intervention in Industrial Transformation" in The Developmental State (1999), Edited by Meredith Woo-Cumings (Cornell University Press) pp. 218219.

${ }^{23}$ Id., pp. 328-329.

${ }^{24}$ Economic Commission for Africa (2011), Economic Report on Africa 2011: Governing development in Africa - the role of the state in economic transformation, Addis Ababa, Ethiopia., p. 7. 
The Report notes that "[i]ssues of market failure abound, requiring the state's positive intervention". 25 It states that "free market forces will not drive economic transformation on their own" and underlines the central role of the state "in resource allocation and in efficient coordination of crucial economic activities" with particular attention to "developing infrastructure, human capital, and the financial market and setting up production facilities in the agricultural and industrial sectors". ${ }^{26}$

According to the Report this needs "a democratic socio-political environment that endows it with legitimacy and authority" and to provide "stakeholders with the voice and representation that enable them to have a sense of ownership of the country's national development programme". ${ }^{27}$

The capacity of the developmental state for formulating and implementing such a programme has two component parts. The first consists of a political leadership that is committed to national development goals and that can motivate and guide the planning process. The second is a competent and professional bureaucracy that has the autonomy and power to implement the programme and respond swiftly to rapidly changing local and global conditions. Its personnel must be recruited solely on merit, well trained and adequately rewarded. ${ }^{28}$

\subsection{Lessons from South Korea's economic performance}

Pirie observes that the Korean developmental state "must be understood as a child of its time". ${ }^{29}$ Korea's industrialization took place in the midst of "Japanese dominated regional production structures" and the involvement of "the US in shaping Korean political economy" in the context of the post-war global development project and the second industrial revolution". ${ }^{30}$ Pirie notes South Korea's "initial underdevelopment and the security situation on the peninsula" which brought about "the project of state-led capitalist development". ${ }^{31}$ While both the South Korean state and post-war core capitalist national industrial states focused very closely on promoting and subsidizing investments of large nationally owned firms, South Korea "was a dirigiste state in a world of interventionist states" and "Korean elites were attempting to

${ }^{25}$ Ibid.

${ }^{26}$ Ibid.

${ }^{27}$ Id., p. 8.

${ }^{28}$ Ibid.

${ }^{29}$ Id., p. 7.

${ }^{30}$ Ibid.

${ }^{31}$ Ibid. 
develop a distinctive Korean capitalism in a world of interconnected but still distinct national capitalisms", ${ }^{32}$

The lessons that are examined regarding South Korea's achievements relate to the policies of its developmental state during the 1960s and 1970s. "In 1960, South Korea was poorer than many sub-Saharan African countries. ... Since then [it has] left far behind not only these African countries, but also others like Mexico and Argentina which had been much richer". ${ }^{33}$

In 1960 South Korea was one of the poorest 25 countries in the world [FN 1]. Its Gross Domestic Product (GDP) per capita was just $\$ 82$ (in 1960 prices). United States (US) policymakers' assessment of the country as a 'hopeless case' appeared apposite at the time. ${ }^{34}$ However, the performance of the Korean economy over the next four decades or so could not have been more different from that predicted by such policymakers in 1960. ... Korea was now a member of the Organisation for Economic Co-operation and Development (OECD) and one of the few countries that appeared to have successfully graduated from the Third World. ${ }^{35}$

In 1961, i.e. the initial year of Korea's developmental state, GDP per capita of various African countries was higher than South Korea's US\$92. For example, African countries that had higher GDP per capita (in US dollars) as compared to South Korea include: Algeria (\$221), Benin (\$96), Cameroon (\$119), Chad (\$111), Congo Democratic Republic (\$199), Congo Rep (\$146), Ivory Coast (\$164), Egypt (\$151), Gabon (\$343), Ghana (\$187), Kenya (\$95) Liberia (\$161), Madagascar (\$134), Morocco (\$169), Niger (\$145), Nigeria (\$95), Senegal (\$262), Sychelles (\$270), Sierra Leone (\$148), South Africa (\$430), Sudan (\$103), Tunisia (\$202), Zambia (\$218), Zimbabwe (\$283). ${ }^{36}$ There has been extensive discourse on the factors that have brought about this development.

South Korea's GDP per capita for the year 2012 is $\$ 22,590$ (GNI in power purchase parity is $\$ 28,231^{37}$ ). The GDP of African countries in 2012 that had

${ }^{32}$ Ibid.

${ }^{33}$ Dani Rodrik (1995), "Getting Interventions Right: How Korea and Taiwan grew Rich”, Economic Policy, Vol. 10, No. 20 (Apr., 1995), p. 55

${ }^{34}$ Hart-Landsberg, M. (1993), The Rush to Development: Economic Change and Political Struggle in South Korea, New York, Monthly Review Press [in Pirie, infra note 26, p. 1]

${ }^{35}$ Iain Pirie (2008), The Korean Developmental State: From dirigisme to neo-liberalism, (Routledge), p. 1.

${ }^{36}$ Source of data: World Bank $<$ http://en.wikipedia.org/wiki/List_of_countries_by_past_and_future_GDP_(nominal) per_capita>, last visited: 10 July 2013.

$37<$ hdrstats.undp.org/en/countries/profiles/KOR_print.html> last visited: 25 July 2013. 
higher GDP per capita figures (in 1961) as compared to South Korea is as Follows. $^{38}$

\begin{tabular}{|l|l|l|l|l|}
\hline Algeria $\$ 5,404$ & Cote d'Ivoire $\$ 1,244$ & Ghana $\$ 1,605$ & Niger $\$ 383$ & S. Africa $\$ 7,508$ \\
\hline Benin $\$ 752$ & Egypt $\$ 3,187$ & Kenya $\$ 862$ & Nigeria $\$ 1,555$ & Sudan $\$ 1,580$ \\
\hline Cameroon $\$ 1,151$ & Ethiopia $\$ 470$ & Liberia $\$ 422$ & Senegal $\$ 1,032$ & Tunisia $\$ 4,237$ \\
\hline Congo Dem. Rep $\$ 272$ & Gabon $\$ 11,430$ & Madagascar $\$ 447$ & Sychelles $\$ 11,758$ & Zambia $\$ 1,469$ \\
\hline Congo Rep $\$ 3,154$ & Gambia $\$ 512$ & Morocco $\$ 2,925$ & Sierra Leone $\$ 635$ & Zimbabwe $\$ 788$ \\
\hline
\end{tabular}

South Korea's Country HDI Profile (2012): Human Development Indicators ${ }^{39}$ show that its performance in health, education, income, sustainability, innovation and technology, trade and economy, and other HDI indicators was indeed commendable. South Korea's Human Development Index (1980 to 2012) shows steadily increasing achievements. ${ }^{40}$

Rodrik recalls the "extremely well-educated labour force relative to their physical capital stock" which rendered "the latent return to capital quite high" and the active support of the state in "subsidizing and coordinating investment decisions" and the role of government policies that were "managed to engineer a significant increase in the private return to capital". ${ }^{41}$ The other factors noted by Rodrik include an "exceptional degree of equality in income and wealth", effective government intervention and "keeping it free of rent seeking. The outward orientation of the economy was the result of the increase in demand for imported capital goods". ${ }^{42}$ Rodrik further notes that in the early 1960 s and thereafter, Korea and Taiwan alleviated the coordination failure in their economies which had blocked take-off and this "required a range of strategic interventions - including investment subsidies, administrative guidance and the use of public enterprise". ${ }^{43} \mathrm{He}$ further notes the favourable human capital endowment and relatively equal distribution of income and wealth. ${ }^{44}$

The support provided by the government went beyond export subsidization and further included increase in subsidy on export credits, exemption of exporters from the commodity tax and the business activity tax, and reduction of income tax on export earnings. ${ }^{45}$ The support offered to promote exports also included "direct cash grants on exports" until 1965. ${ }^{46}$ Moreover, exporters "were allowed automatic access to duty-free imports of raw materials and intermediate

${ }^{38}$ Compiled from: $<$ http://data.worldbank.org/indicator/NY.GDP.PCAP.CD $>$ Last visited: 25 July 2013.

$39<$ hdrstats.undp.org/en/countries/profiles/KOR_print.html>, last visited: 23 July 2013.

${ }^{40}$ Ibid.

${ }^{41}$ Rodrik, supra note 33.

${ }^{42}$ Ibid.

${ }^{43}$ Id., p. 57

${ }^{44}$ Ibid.

${ }^{45}$ Id., p. 61.

${ }^{46}$ Ibid. 
inputs up to a limit" which "was determined administratively, on the basis of firms' and industries' input-output coefficients plus a margin of 'wastage allowance'." ${ }^{47}$

Bagchi $^{48}$ observes various factors that contributed to Korea's economic success during the 1960s and 1970s. He recalls Korea's colonial experience under Japan since 1910, US influence until the late 1950s and the land reform that triumphed over landlordism. He observes that the Korean government obtained a large stock of industrial assets from the confiscation of Japanese property "and a substantial percentage of the cultivable land which could then be distributed to the Koreans" followed by significant land reform measures. ${ }^{49}$ "As a result of the land reform process, between 1947 and 1965, the percentage of full owners among farm households increased from 16.5 to 69.5 , whereas that of pure tenants declined from 42.1 to 7.0 only". This land reform which was pro-peasant relatively equalized rural incomes and assets thereby eliminating land "as an asset for speculation or as a lever for keeping actual producers dependent". ${ }^{50}$ Bagchi regards this as one of the conducive conditions and further identifies "a strong and realistic sense of nationalism" as another significant factor in Korea's economic success. ${ }^{51}$

The other conditions identified by Bagchi that assisted the pursuits of the developmental state in Korea are the gains in import substitution efforts during the 1950s, commendable achievements in education, "privileged access South Korea enjoyed to U.S. capital and U.S. markets, especially in the 1960s and 1970 s, export-led growth that had a strong foundation from the achievements obtained in the earlier decade and institutional capabilities that steadily developed since the 1950s. ${ }^{52}$ Bagchi notes the sustained improvements in productivity through rising levels of education of the workforce, learning by doing and learning by using, and exploitation of economies of scale through the favoured treatment of large firms especially in exports". ${ }^{3}$

In the course of achievements in Research and Development initiatives by government and industries, "a deliberate restructuring of industry" was made which focused on sectors such as "shipbuilding, electronics, automobiles, iron and steel, and petrochemicals". 54 The success in "domestic investment and

${ }^{47}$ Ibid, [citing Charles R. Frank et al (1975), Foreign Trade Regimes and Economic Development: South Korea, (New York: Colombia University Press)]

${ }^{48}$ Amiya Kumar Bagchi (2004), The Developmental State in History and in the Twentieth Century (New Delhi: Regency Publications).

${ }^{49}$ Id., p. 41.

${ }^{50}$ Id., p. 42.

51 Ibid.

${ }^{52}$ Id., p. 44.

${ }^{53}$ Id., pp, 44-45.

54 Ibid. 
saving, the growth of national income, and exports of manufactures" were enhanced and, "the close collaboration between government and business, and the effective monitoring by government of strategic business decisions played a highly important role". ${ }^{55}$ As the manufacturing sector of South Korea developed, large surpluses were generated in its exports, and "the Korean government played a less interventionist role in the economy; and many of the formal restrictions on entry of foreign goods and foreign capital were relaxed, partly under the pressure of the US government and foreign transnational corporations". 56

\subsection{Lessons from South Korea about the limits of developmental states}

As Korea's experience indicates, there is a phase of obsolescence of the developmental state during which its role in enhancing economic development outlives its usefulness because wider state intervention in the economy eventually becomes undue patronage and red tape, as marked by the massive labour unrest of the 1980s and Korea's 1997 economic crisis. One of the lessons that can be learnt from Korea's experience is that the developmental state nurtures and facilitates the coalescence of an economic system to which it at a later stage becomes an impediment.

${ }^{55}$ Ibid.

${ }^{56}$ Id., pp. 45-46. "In the 1990s, the South Korean DS [developmental state] entered into a phase of precocious maturity and decline. Several factors contributed to this. The deliberate promotion of chaebol by the South Korean government up to 1982-83 - and in many cases, even beyond that date - created a number of South Korean transnational corporations which set up branches and subsidiaries in many countries of the world, including the U.S.A., Canada and major European countries.

The latter now demanded freer entry for the investments and products of their firms into South Korea. Until 1993 or thereabouts, South Korea, following the Japanese example had kept inward foreign investment at bay. After that year, restrictions on foreign portfolio and direct investment were relaxed and a much greater mobility of capital was permitted in international transactions. This led to an inflow of foreign capital. Moreover, the Japanese yen and the Chinese yuan were substantially devalued from around the same date. These developments led to an overvaluation of the Korean currency, and South Korea ran up large deficits in its balance of payments. South Korean firms borrowed large amounts abroad to take advantage of lower interest rates abroad. By the beginning of 1997, South Korea was caught in a debt trap, and in the last quarter of that year, it had to seek IMF assistance in order to avoid declaration of debt default (Bagchi, 1998). The usual IMF conditionalities ended at least temporarily, South Korea's status as a DS." Bagchi, p. 46. 
The concurring motives of both major actors in the process (i.e. the developmental state and the large capitalist firms) are different. Unlike the conventional modern minimal state which is usually part of the capitalist economic system, the developmental state does not promote its own class interests, but rather targets at the bigger picture of economic development of the nation at large. This creates tension in the developmental state's raison d'être of developing private capital which is manifested in its economic strategy "of developing and supporting large national capitalist firms" and its act of dominating and controlling these firms". The developmental state in South Korea did not act at the behest of the capitalist class - which it itself created but it was committed to acting in its interests". 57

Despite such tension in the concurrent motives of the state and the major economic actors, the ultimate outcome of teaming up brought about commendable achievements throughout the 1960s and this setting enabled quick recovery from the crisis of the early 1970s. However, Korea's experience indicates the eventual limits in the pursuits of developmental states. These limits are influenced by the contradictions that are inherent in developmental states.

The first contradiction relates to the role of the state as the "provider of longterm goals for the economy" and the eventual decline of its positive role in the economy. The developmental state establishes "comprehensive economic development plans, long-term goals, and projections for the entire economy", furnishes "capital for investment through domestic and foreign capital loans, capital assistance for research and development, and technology and technical assistance through national and regional research facilities" and further "acts as a mediator with multinational corporations for foreign direct investment and technology transfers, establishes trade offices for expertise on exports and imports, provides tax breaks and tariff exemptions, and eases regulations". ${ }^{58}$ These services are offered to the private sector because the latter initially "lacks resources and knowledge". In the long run, however, the state becomes a hindrance to the "modern economy's vitality and speed by becoming bureaucratic "red tape"" when the pursuits of the developmental state become successful. ${ }^{59}$

Unlike other forms of states, the function of the developmental state is transitional and the successful attainment of its goals causes a steady decline in

${ }^{57}$ Pirie, supra note 35, p.6. [citing Cumings, B. (1979). 'The origins and development of the Northeast Asian political economy: industrial sectors, product cycles, and political consequences', International Organization, 38(1): 1-40]

58 Eun Mee Kim (1993), "Contradictions and Limits of a Developmental State: With Illustrations from the South Korean Case" Social Problems, Vol. 40, No. 2 (May, 1993) p. 231-232 [citing various sources].

${ }^{59}$ Id., p. 232. 
its importance. For example, "[t]he welfare state attempts to remedy the problems left unresolved by the private sector" and the successful provision of "welfare services to the public does not change the fundamental assumption that the private sector is incapable of and/or unwilling to provide these services, and that the state must provide them". ${ }^{60}$ Likewise, the laissez faire state "assumes from the beginning a relatively confined (regulatory rather than developmental) and augmentative role in relation to the private sector. Even with successful economic growth, no significant transition of power to the market is needed, since the private sector is in charge from the beginning". 61

The second contradiction that emerges upon the success of developmental states is the steady blurring of its autonomy in the course of economic development. The autonomy of the developmental state emanates from the fact that it does not emerge as a representative for "the landed or capitalist classes, [and this] insulates state officials from the influence of their own class interests". As the developmental state succeeds, its autonomy is gradually eroded because "[d]evelopment brings wealth and power to new classes and social groups (Koo $1990^{62}$; Suh $1984^{63}$ ), who use their newly acquired status to press for more independence" and this "threatens the core of the developmental state, which is its autonomy and its mandate to intervene in the economy". 64

Kim states that "South Korea's military junta government in 1961-63 were not part of the small, wealthy capitalist class, but instead had rather modest backgrounds. President Park Chung Hee himself was from an impoverished peasant family". 65

However, the separation of state elites from landed or capitalist classes is only a short-lived phase in the process of capitalist development. Successful and very rapid development brought drastic changes not only to the economy, but to the society as well. The historical class distinction between state officials and merchants and industrialists was no longer clearly applicable (Koo 1990), and the upper class in a new social order included merchants and industrialists as well as state officials (Suh 1984). Moreover, through intermarriages between the offspring of capitalists and state elites (forbidden during the Yi Dynasty), the class distinction has become even

${ }^{60}$ Ibid, [citing Evans 1987]

${ }^{61}$ Ibid.

${ }^{62}$ Ibid, [citing Hagen Koo (1990) "From farm to factory: Proletarianization in Korea." American Sociological Review 55:669-81]

${ }^{63}$ Ibid, [citing Gwan-mo Suh (1984) Class Composition and Class Division in Contemporary Korean Society. Seoul: Hanul]

${ }^{64}$ Id., p. 232.

${ }^{65}$ Ibid. 
more blurred (Shin and Chin 1989) ${ }^{66}$. The process of fusion of state elites and capitalist elites weakened the fabric of state autonomy. ${ }^{67}$

The steady erosion in the autonomy of the developmental state is further enhanced by the tension between 'the self-limiting' features of the developmental state which remains an autonomous political and administrative entity while the core social groups, i.e. labour and the "capitalist class [grow] in size and in political influence with development" and these "newly strengthened classes and groups can significantly challenge the state's power and its mandate in economic relations". ${ }^{68}$

\section{Lessons from Land Reforms in South Korea and Taiwan}

\subsection{Land reform in South Korea}

In the realm of secure property rights South Korea, along with Taiwan, stand $4^{\text {th }}$ out of 32 Asian countries ranking after Hong Kong, Singapore and Japan. ${ }^{69}$ Korea was largely agrarian under a feudal system until World War II and "the country was split into North and South, with both countries enacting major land reform and outlawing tenancy on agricultural lands. While the economy in the communist North has stagnated, South Korea has developed a modern, market economy". 70

South Korea's 1948 Constitution embodied agricultural land reform and it marked a departure from its feudal landholding system. South Korea's Agricultural Land Reform Amendment Act (ALRAA) was in force since March 1950. The act enabled individuals to own agricultural land under three conditions: "first, any individual can own agricultural land but only if he or she cultivates or manages it for himself or herself; second, one can own

${ }^{66}$ Ibid [citing Eui Hang Shin, and Seung Kwon Chin (1989) "Social affinity among top managerial executives of large corporations in Korea." Sociological Forum 4:3-26].

${ }^{67}$ Id., pp, 232-233.

${ }^{68}$ Id., p. 233.

${ }^{69}$ 〈http://www.globalpropertyguide.com/Asia/South-Korea/property-rights-index», Last visited: 22 October 2013.

${ }^{70}$ Justin Maloney (2000), Land Tenure History and Issues in the Republic of Korea (University of Maine, Department of Spatial Information Science and Engineering) May 2000 , p. 7.

〈http://www.spatial.maine.edu/ onsrud/Landtenure/CountryReport/Korea.pdf〉, last visited: 30 October 2013. 
[approximately] three [hectares] at maximum; and third, tenancy arrangements and land-renting activities are legally prohibited." 71

Extremely low land prices during this period had helped make the ALRAA possible. With the breakdown of order in society following World War II, landlords saw the rents they were able to extract from tenants drop sharply, if they could collect them at all. Many were forced into selling their lands at low prices, and approximately $37 \%$ of the arable land was sold between 1945 and 1949. This huge supply of available land negated the effects of millions of returning refugees and made a major redistribution possible. As a result the ALRAA was very successful, resulting in the near-complete elimination of tenant farming and an increase in owner-cultivating households from 349,000 in 1949 to $1,812,000$ in $1950 .^{72}$

The instability and post-WWII challenges rendered reforms and radical changes indispensible in South Korea. While the tenants highly benefitted from the land reforms, the landlords were also compensated thereby creating a favourable setting for the enhancement of non-agricultural rural economic activities as well. Unlike North Korea, land was not redistributed without payments. Due to government intervention in expediting the payment of compensation to landlords whose land (beyond the threshold allowed to be owned) was distributed to tenants, the tenants made the payments at a prolonged period and a reasonable amount because the price of land was extremely low during the period.

This was in contrast with the land reform in North Korea which led to economic stagnation. In South Korea, the land reform was accompanied by land tenure and land security. It broadened the mass base in land ownership whereas North Korea pursued the path of nationalization without compensation to the landlords, and allocated the land to communes whose members did not claim individual tenure and security. While the land reform applied in North Korea culminated in economic stagnation due to the communal system, the South Korean experience indicates the merits in empowering smallholder farmers through the creation of an enabling environment for land purchase and ownership and at the same time availing compensation to former land owners (other than the ones that were regarded as illicit large scale possessions such as Japanese colonialists). Moreover, the land reform eventually led to farmland consolidation and modern agriculture rather than farmland fragmentation, and it

${ }^{71}$ Ibid, [citing Jeon, Y.-D. and Y.-Y. Kim (2000). "Land Reform, Income Redistribution, and Agricultural Production in Korea." Economic Development and Cultural Change, 48(2): 253.

${ }^{72}$ Ibid. 
marked a strong basis for the emergence and coalescence of modern industrial economy.

South Korea's experience in land rights clearly shows that the smallholder farmer was empowered with secure property rights and tenure because he/she does not merely hold the land but owns it. Nor did it entail the risk of mass eviction though manipulations from property speculators because owners were required to cultivate or manage the farm, in addition to which a ceiling was made to the area of individual ownership of land. As South Korea's economy kicked-off and along with the maturity of its industrial economy the restrictions imposed during the initial stages of the land reform gradually gave way to farmland consolidation and modern agriculture with the optimal levels of tenure and security in land rights.

\subsection{Land reform in Taiwan and requisition for industrial use}

The land reform in Taiwan was conducted from 1949 to 1953. The reform involved rent reduction as the primary phase (1949), followed by the sale of public land in 1951 and the transfer of land to actual tillers (initiated in 1953) ${ }^{73}$ through the compulsory purchase of farmland to resell it to tillers. As Koo observes:

Taiwan underwent two distinct stages of agricultural development. The first phase from 1895 to 1945, while the island was under Japanese control, witnessed the introduction and extension of modern technology. There was large scale development of water resources and technological improvement in rice and sugar cane production under the promotion of the Japanese government. During the second phase-1945 to the present-the impetus to agricultural development was provided by the land reform program introduced after the end of the Second World War. ${ }^{74}$

The Nationalist Party (Kuomintang) had failed to address the reform motto of land to the tiller in mainland China until it was ousted by the communists in 1949. After it left the mainland, its power was confined in the island which was part of China until the Chinese Communist Party overthrew the Kuomintang. The affiliation of the Kuomintang with the landed gentry in mainland China did not make such reform possible. However, the party which was an outsider to Taiwan and unattached to its landed gentry, did not dare to repeat its mistake regarding land reform. As Hsiao notes, the Nationalist Party undertook land

\footnotetext{
${ }^{73}$ Anthony Y. C. Koo (1966), "Economic Consequences of Land Reform in Taiwan", Asian Survey, Vol. 6, No. 3 (Mar., 1966), p. 150.

${ }^{74}$ Ibid.
} 
reform which "turned the rural sector from potential source of unrest into a fundamentally conservative social base". 75

The first measure taken by the Nationalist government (Kuomintang) after it moved to Taiwan from the mainland was the reduction of rural land rent which fixed the maximum total yield to be given to the landlord at $37.5 \%$. The reform also allowed temporary reduction of the sharecropping as land rent during crop failure.

The second phase of the land reform involved the transfer of land to the actual tillers when the government started to sell state-owned land to tenants. This reform was preceded by peasant movements in 1947 and 1948 against state-owned Taiwanese Sugar Company. ${ }^{76}$ "More than fifty per cent of the farmland owned by the central and provincial government" was transferred and 'cultivators of public land, and other tenant farmers, were given first and second priority respectively for the purchase of public land" at a price "set at 2.5 times the annual yield of the annual crops ... to be paid in twenty instalments over a period of ten years". ${ }^{77}$

The third phase of the land reform took place upon the enactment of the 1953 Land-to-the-Tiller $\mathrm{Act}^{78}$ and the Regulations Governing the Implementation of the Act. "T9 "There were 26 grades for paddy land and 26 grades for dry land." The Act "limited land holdings to roughly three cha (about 2.9 hectares) of medium quality ( $7^{\text {th }}$ to $12^{\text {th }}$ grade) of paddy land or its equivalent." ${ }^{\text {"81 }}$ All land in excess of this size was compulsorily purchased by the government for redistribution.

The landlords were compensated with a price of 2.5 of the annual yield of the land. They "were paid 70 per cent of the purchase bond in Commodity Bonds, i.e. ten-year bearer government bonds, redeemable in either rice or sweet potato,

\footnotetext{
${ }^{75}$ Michael H. H. Hsiao (1988), "State and Small Farmers in East Asia with Special Reference to Taiwan", paper presented at Conference on Directions and Strategies of Agricultural Development in Asia-Pacific Region, Academia Sinica, Taipei, January 5-7, 1988 [in Ming Yu-Hom, infra note 47, p. 90.]

${ }^{76}$ Shih-jung Hsu and Hsin-huang Michael Hsiao (2001), “Taiwan's Land Reform Revisited: From the Vantage Point of Its Domestic Social Origins", Taiwan Historical Research, Vol. 8 No. 1, p. 123, June 2001, Issued October 2001. Institute of Taiwan History, Preparatory Office, Acadamia Sinica.

${ }^{77}$ Ming Yu-Ho (1997), "Law, Foreign Direct Investment and Economic Development in Taiwan", PhD Thesis, (University of Warwick School of Law, August 1997), p. 91.

${ }^{78}$ Enacted on January 20, 1953.

${ }^{79}$ Enacted on April 23, 1953.

${ }^{80}$ Ming Yu-Ho, supra note 77 (1997), p. 91. [citing Samuel P. S. Ho (1978) Economic Development of Taiwan 1860-1970, New Haven: Yale Univ. Press, p. 61).

${ }^{81}$ Ibid.
} 
depending on whether the land was paddy-field or dry". ${ }^{22}$ Moreover, these Bonds "paid a 4 per cent annual interest" and the remaining balance of 30 (thirty) per cent of the purchase price "was paid in shares of stock in four government enterprises shortly transferred to the private sector". ${ }^{83}$ Such payment in stock shares in public enterprises "had the effect of converting investments in land into industrial assets and laying the foundation for the industrialization of Taiwan". ${ }^{84}$

During the period between May to December 1953, the land was sold to "its former tenant farmers at the same price it had been purchased" and the buyers received government loans to be paid "in ten annual instalments and a 4 per cent annual interest rate in rice (for paddy land) and in sweet potatoes, converted to cash (for dry land)". ${ }^{85}$

Ming Yu-Ho states three outcomes of the reform. ${ }^{86}$ Agricultural production rose $43 \%$ from 1952 to 1960 , and rice yield per hectare increased by $25 \%$ during the same period. Secondly, the reform and the compensation schemes directed former landlords to urban businesses thereby enhancing domestic investment. And the third impact of the reform was the industrialization that benefited from the conducive environment created by agricultural surplus and the enhanced entrepreneurship of former landowners whose interest changed from agriculture to businesses and ultimately to industrialization. "Under conditions prevailing in Taiwan, the improvement in the efficiency of agricultural production was a logical first step toward industrialization". ${ }^{87}$ There were also other concurrent factors that facilitated industrialization. As Thuemmel notes, education institutions, "island-wide network of farmers associations" (that existed since 1944), and the fact that over a million educated and well-trained mainland Chinese fled to Taiwan have contributed to Taiwan's economic performance in addition to the land reform. ${ }^{88}$

${ }^{82}$ Ibid [citing Simon Long (1991) Taiwan: China's Last Frontier, London: MacMillan, p. 78].

${ }^{83}$ Id., p. 92 [citing, Ralph N. Clough (1978) Island China, Massachusetts: Harvard University Press, p. 73].

${ }^{84}$ Thomas R. Bowden (1961), "Land Reform and Rural Development on Taiwan", University College Review, Institute of Ethiopian Studies, Vol. 1, No. 1 (Spring, 1961), p. 34.

${ }^{85}$ Ming Yu-Ho, supra note 77, p. 92 [citing Ralph N. Clough (1978) Island China, Massachusetts: Harvard University Press, p. 73 \& Simon Long (1991) Taiwan: China's Last Frontier, London: MacMillan, pp. 162-63]

${ }^{86}$ Id., p. 93.

${ }^{87}$ Anthony Y. C. Koo (1966), "Economic Consequences of Land Reform in Taiwan", Asian Survey, Vol. 6, No. 3 (University of California Press , Mar., 1966), p. 157

${ }^{88}$ William L. Thuemmel (1969), Book Review "The Role of Land Reform in Economic Development: A Case Study of Taiwan" by Anthony Y.C. Koo; The Journal of 
Various factors have contributed for the success of the land reform in Taiwan. These factors include the land survey carried out during the period of Japan's control and the compensation paid to landlords and the effective control of inflation against decrease in the value of compensation. Moreover, the National government was an outsider which had autonomy from the Taiwanese landed gentry. This enabled it to have utmost flexibility in decisions because the National government did not depend on the support of the landed gentry.

Sun Yat-Sen's principles have consistently influenced the National government's land use laws. One of Sun's core principles "is the Principle of People's Livelihood" whose realization envisaged the 'equalization of land rights' and the 'regulation of capital' with a view to securing "an even, nationalized distribution of the benefits of land as a natural resource, while preserving private ownership of land" 89

Articles 142 and 143(1) of the 1947 Constitution of Taiwan (with amendments through 1987) provide the following:

\section{Article 142}

The national economy shall be based on the principle of people's livelihood and shall seek to bring about an equal distribution of land rights and regulate the use of private capital in order to ensure an equitable distribution of national income and a sufficient livelihood for the people.

\section{Article 143}

1. All land within the territorial limits of [Taiwan] shall belong to the entire body of citizens. Private ownership of land, acquired by the people in accordance with the law, shall be protected and limited by law. Privately owned land shall be liable to taxation according to its value and may be purchased by the Government according to its value.

As Bishai observes " $t$ t]his constitutional framework is based on Sun's notion of the state as mediator between the primary public ownership and the individual private owner". ${ }^{90}$ After the land reform was implemented based on the principle of people's livelihood, there was the need to facilitate Taiwan's transition to industrialization. In effect, a Statute for Encouragement of Investment was promulgated on 10 September 1960 and subsequently had series of amendments. This law articulated the manner in which land was transferred to industries to enhance industrial economy.

Developing Areas, Vol. 3, No. 4 (College of Business, Tennessee State University, Jul., 1969), pp. 590-591.

${ }^{89}$ Martha Fitzpatrick Bishai (1991), "The Development of Industrial Land in Taiwan:

A Legal Framework for State Control”, The Journal of Developing Areas, Vol. 26, No. 1 (College of Business, Tennessee State University, Oct., 1991), p. 54.

${ }^{90}$ Id., p. 56. 
Chapter III of the Statute is titled "Acquisition of Land for Industrial Use," and Article 50 provided that "... the Executive Yuan shall first allocate public land areas to be designated as industrial land for industrial development purposes." It further stipulated that in the event that public land is insufficient for such allocation, "private land may be converted for use and designated as industrial land." After such designation, the land will be frozen. This measure includes prohibition of construction and transfer after which detailed plan of requisition is drawn. Thereafter " $[\mathrm{t}] \mathrm{he}$ land administration sets a date on which the owners of the designated land are to negotiate and to 'agree upon the price of compensation for the land.' If agreement is not reached, the government (through its Committee for Assessment of Standard Land Value) assesses a price."

The Statute ensured that holdouts by land owners through exaggerated price offers shall not hamper the requisition, and at the same time recognized payment of the market price to the land. According to Article 56 of the Statute the land requisitioned in accordance with the Statute "shall be compensated for the market price through negotiation and agreement. The market price ... means the prevailing price, in general transaction, of the land in the locality, used for the same purpose as the requisitioned land is used prior to its requisition". This provision allowed the state to set land prices where negotiation fails. "Most often, however, the state would actually purchase the land, develop it for industrial use, and then sell or lease it to the industrial user" ${ }^{\text {"91 }}$ in order to "prevent the disastrous effects of land speculation". 92

\section{China's Land Rights Regime: An Overview}

\subsection{Options and challenges in land rights}

The economic reforms in China since 1979 are reflected in its legal regimes and economic policies including property rights. ${ }^{93}$ These reforms are gradual and cautious even if market forces are steadily allowed to have impact in the economy. China still considers its economy as 'socialist' but with 'Chinese characteristics'.

The three options that were deliberated upon in post-1979 China with regard to land rights were privatization, state ownership in lieu of the rights vested on the communes, and choosing among the variations of collective ownership managed by the villages themselves (i.e. natural villages) or by administrative

\footnotetext{
${ }^{91}$ Id., p. 58.

92 Id., p. 61.

93 See Land Administration Law (promulgated on June 25, 1986, revised Dec. 29, 1988, Aug. 29, 1998, and Aug. 28, 2004, effective Aug. 28, 2004); and Law on Land Contract in Rural Areas (promulgated., Aug. 29, 2002, effective March 1 2003).
} 
villages. ${ }^{94}$ China has opted "to avoid widespread social conflict over land" and "the central government decided - with good reason - to leave collective land ownership undefined" along with a similar approach in the definition of the 'state-owned land' because "it was unclear which administrative level represented ownership". ${ }^{95}$ In spite of these gaps in specificity, China decollectivized the post-1949 village communes and introduced Household Contract Responsibility Systems for agricultural land (or cropland) in such a manner that productivity and incentives could be encouraged without a hasty reversal of the collective ownership regime. Accordingly, households entered into lease contracts with the collective which owns the land and to which they are members.

These gaps in the definition of collective land ownership had various downsides including administrative abuse from executive office holders:

As it is unclear which level of the collective is legally entitled to represent land ownership, corrupt local cadres have a powerful incentive to sell land that is not theirs. The clearest example of such dark practices was the dishonourable discharge in October 2003 of Tian Fengshan, Minister of Land Resources. Tian was charged with corruption and land theft during his term as governor of Heilongjiang Province from 1995 to $1999 . .$. Over the years, many farmers have been faced with forced eviction from their land as entire villages have been [allocated] for real estate development. It was estimated that over the period 1985-96 the total loss in arable land due to construction activities amounted to 1.3 million ha. ... Since China has only one third of the world country average of arable land, these losses also threaten China's food security. ${ }^{96}$

Even if the village collective continued to retain the bare ownership of rural land in China, the administrative village leased out land to individual households (under the Household Contract Responsibility System) which led to fragmentation and challenges to environmental planning and protection.

${ }^{94}$ Peter Ho (2005), Institutions in Transition: Land Ownership, Property Rights and Social Conflict in China (Oxford University Press). "In 1998 there were 739,980 administrative villages as against almost 1.5 million natural villages”. (p. 193).

${ }^{95}$ Id., p. 188.

${ }^{96}$ Id., p. 190 [citing Garrie van Pinxteren, 'Chinese Minister Ontslagen' ('Chinese Minister Sacked'), NCR Handelsblad (23 October 2003), p. 4.; and Ministry of Agriculture, China Agricultural Development Report (Beijing: Nongye Chubanshe, 1997), p. 100. 


\subsection{Compensation for expropriation of rural land under China's Land Administration Law}

China's Land Administration Law (LAL) was enacted in 1988, and there have been two amendments in 1988 and 2004. It maintains socialist public ownership of land ${ }^{97}$ which is defined as "ownership by the whole people and collective ownership by the working people". 98 The law classifies land into "land for agriculture, land for construction and unused land" and pledges to "keep the total area of land for construction under control". 99 The procedures of expropriation and the compensation paid upon expropriation are criticized in various literature. Yet, there are positive developments of steady reform.

According to Article 47 of China's Land Administrative Law, the compensation upon the expropriation of rural land includes (a) compensation for the land, (b) resettlement subsidies and (c) compensation for attachments and young crops on the requisitioned land.

"Compensation for expropriated of cultivated land shall be six to ten times the average annual output value of the expropriated land, calculated on the basis of three years preceding such requisition. ... The standard resettlement subsidies to be divided among members of the agricultural population needing resettlement shall be four to six times the average annual output value of the expropriated cultivated land calculated on the basis of three years preceding such expropriation. However, the maximum resettlement subsidies for each hectare of the expropriated cultivated land shall not exceed fifteen times its average annual output value calculated on the basis of three years preceding such expropriation". ${ }^{100}$...

In case the land compensation and resettlement subsidies stated above "are still insufficient to enable the peasants needing resettlement to maintain their original living standards, the resettlement subsidies may be increased" without, however, exceeding "30 times the average annual output value of the expropriated land calculated on the basis of three years preceding such expropriation". ${ }^{101}$

\subsection{China’s 2007 Property Rights Law}

After long deliberations and rehearsals in various policy options, China has in 2007 enacted its property rights law. The amendment of Article 10 of the Chinese Constitution in $1988^{102}$ was a fundamental step toward the enhancement

${ }^{97}$ Land Administrative Law of the People's Republic of China, Article 1.

${ }^{98}$ Id., Art. 2.

${ }^{99}$ Id., Art. 4.

${ }^{100}$ Id., Art. 47.

${ }^{101}$ Ibid.

102 April 18, 1988. 
of the scope of land use rights in China. The fourth paragraph of Article 10 of the Constitution, which provided that "no organization or individual may appropriate, buy, sell or lease land or otherwise engage in the transfer of land by unlawful means," was amended as: "No organization or individual may appropriate, buy, sell or otherwise engage in the transfer of land by unlawful means. The right to the use of land may be transferred according to law." This constitutional framework which allowed the transfer of the right to the use of land became conducive to legal reform in China's property rights regime.

The 2007 Property Rights Law of China recognizes three forms of ownership: state, collective and individual. It also embodies provisions on usufruct rights (Articles 117-123). The general stipulations on ownership (Articles 39 to 42), inter alia, include:

- "the right to possess, utilize, dispose of and obtain profits from its real or movable property in accordance with the laws" (Art. 39) ;

- "the right to establish usufruct and security right in property rights with regard to its real or movable property"(Art 40); and

- the obligee's duty not to do harm to the rights and interests of the usufruct and security right holders while the latter exercise their rights (Art. 40).

Article 42 of China's Property Rights Law allows, 'for the purpose of public interest', the expropriation of "collectively-owned land, houses and other real property owned by institutes or individuals" in accordance with the law. According to the same provision, the compensation for collectively-owned land includes "compensations for the land expropriated, subsidies for resettlement, compensations for the fixtures and the young crops on land", and it further provides that "the premiums for social security of the farmers whose land is expropriated shall be allocated in full, in order to guarantee their normal lives and safeguard their lawful rights and interests".

Paragraph 3, Article 10 of the Chinese Constitution (as amended by Article 20 of Amendment 4 to the Constitution of the People's Republic of China 2004) reads "The state may, for the public interest, expropriate or take over land for public use, and pay compensation in accordance with the law." This stipulation replaces the former version which provided that " $[\mathrm{t}] \mathrm{h}$ e state may, for the public interest, take over land for its use in accordance with the law." The word 'for its use' now reads 'public use', and the payment of compensation is also included.

Property that belongs to the whole state means ownership by the whole people and "[t]he State Council shall, on behalf of the State, exercise the ownership" (Art. 45). Such property includes mineral resources, waters, sea areas (Art. 46). Urban land is also owned by the state (Art. 47) subject to the exception that "the right to the use of residential housing land shall enjoy the right to possess and utilize such land as collectively owned" (Art. 152). "All natural resources such as forests, mountains, grassland, unclaimed land and 
beaches are owned by the State, with the exception of the resources that are collectively-owned in accordance with the law" (Article 48). There are also other resources that may be owned by the state in accordance with the law. These include outskirts of urban areas, wild animals, cultural relics, public facilities such as railways, roads, electric power, communications, gas pipes etc (Arts 46, 49, 51, 52).

Rural land is collectively owned and this includes all resources not owned by the state (Art. 58). There can also be collectively owned urban property (Art. 59). Under these regimes, land can be transferred to individuals or legal persons through contract arrangements. Articles 124 to 134 deal with farmland use rights. These rights can extend to thirty years, or up to fifty years for grassland, and up to seventy years for forests (Art. 126). There are recent policies (highlighted below under Section 3.4) that seek to extend such timeframes into indefinite time.

The person who has the land use right is "entitled to circulate such right by adopting such means as subcontract, exchange and assignment in accordance with the provision of the Rural Land Contract Law" subject to the condition that the "circulated term may not exceed the remaining period of the contract term." (Art. 128). Within the framework of state ownership of urban land, a person who holds use right over a plot of land is referred to as "the owner of the right to the use of land for construction". This shows that the holder of urban land in China owns not only the fixtures on the land but is also unequivocally considered as the owner of the right to use the land. The following provisions are cases in point:

- "The owner of the right to the use of land for construction use shall, according to law, be entitled to possess, utilize and obtain profits from the State-owned land, and have the right, by utilizing such land, to build buildings and their accessory facilities". (Article 135)

- "The ownership of the building, structure and their accessory facilities built by the owner of the right to the use of land for construction use shall belong to such owner, unless there is evidence to the contrary sufficient to invalidate that". (Article 142)

- "Except as otherwise provided for by law, the owner of the right to the use of land for construction use shall have the right to transfer, exchange, make as capital contribution, donate or mortgage the right to the use of land for construction use". (Article 143)

- "Where the owners of the right to the use of land for construction use transfer, exchange, make as capital contribution, donate to others or mortgage the right to the use of land for construction use, the parties concerned shall enter into corresponding contract in writing. The term of such contract to be determined by parties concerned shall not exceed the 
remaining duration of the right to the use of land for construction use". (Article 144)

Although urban land is in principle state-owned, "[t]he owner of the right to the use of residential housing land shall", as stated above "enjoy the right to possess and utilize such land as collectively owned, and the right to build residential house and its accessory facilities on such land". (Article 152). In other words, the scope of the use rights in urban land that is used for residential purposes may be comparable to the one held in rural areas as farmland.

In the property rights discourse, utmost focus is not given to "who 'owns' land", but rather to "the formal and informal provisions that determine who has a right to enjoy benefit streams that emerge from the use of assets and who has no such rights". ${ }^{103}$ Even if the ownership of land in China is vested in the state or the collective, the 2007 Property Rights Law clearly defines the nature and scope of use rights. Not only are the rules regarding the elements of use rights defined, the enforcement mechanism is also stipulated.

\subsection{Current pursuits of further reform in rural land rights}

Since 1978/79, China is steadily moving along the path of various reforms including property rights. It has "moved from a communal system of farming to a system that grants more extensive land-use rights to individual households" enabling rural China to march toward greater prosperity. ${ }^{104}$ Farmers are given thirty-year contractual rights under the Land Administration Law "and the Law on Rural Land Contracting strengthens this right by more specifically enumerating requirements for land contracting and the transfer of contractual rights". ${ }^{105}$ With a view to further rural reform "the government has issued two policy directives that outline measures to increase land tenure security with the goals of doubling farmers' incomes by 2020 and maintaining the country's grain supply". ${ }^{106}$

Such reforms in rural China can indeed increase "the prosperity of the countryside" which, inter alia, "would benefit the Chinese economy as a whole

${ }^{103}$ Shimelles Tenaw, K.M. Zahidul Islam \& Tuulikki Parviainen (2009), "Effects of Land Tenure and Property Rights on Agricultural Productivity in Ethiopia, Namibia and Bangladesh", University of Helsinki, Department of Economics and Management, Discussion Papers n:o 33, Helsinki 2009, p. 8 [citing (Bromley 1991, Eggertsson 1990, Libecap 1989)].

${ }^{104}$ Robin Dean and Tobias Damm-Luhr (2010), "A Current Review of Chinese Landuse Law and Policy: A "Breakthrough" in Rural Development", Pacific Rim Law \& Policy Journal, Vol. 19, No. 1, p. 121.

${ }^{105}$ Ibid.

${ }^{106}$ Ibid. 
by increasing domestic demand". ${ }^{107}$ Policy documents issued after the 2007 Property Rights Law (known as the 2008 Decision and the 2009 No. 1 Document of the Chinese Communist Party) "promote three major changes to rural land-use law". ${ }^{108}$ Primarily, "the Policy Documents indicate that the contractual land-use terms will expand from thirty to an indefinite number of years". ${ }^{109}$ Moreover, these reforms can "spur the growth of rural land-use rights markets" and reinforce the commitment to maintain the agricultural use of farmland by reducing the conversion of agricultural land to non-agricultural uses. $^{110}$

\subsection{China's Administrative Laws}

Various laws have been enacted in China toward due process in administrative procedures, transparency, accountability, judicial review and the redress available in the event of abuse of authority. The purpose of China's Administrative Procedure Law ${ }^{11}$ enacted 1989, include "protecting the lawful rights and interests of citizens, legal persons and other organizations, and safeguarding and supervising the exercise of administrative powers by administrative organs in accordance with the law". ${ }^{112}$ According to Article 2 of the Administrative Procedure Law (APL), any "citizen, a legal person or any other organization" is entitled to bring a suit to court if he/she/it "considers that his/her or its lawful rights and interests have been infringed upon by a specific administrative act of an administrative organ or its personnel". The court shall thereupon "exercise judicial power independently with respect to administrative cases, and shall not be subject to interference by any administrative organ, public organization or individual", and to this end, the courts "shall set up administrative divisions for the handling of administrative cases". ${ }^{113}$ These benches are required to "base themselves on facts and take the law as a criterion" and "examine the legality of specific administrative acts". ${ }^{114}$

Subject to the exceptions stated under Article 12 of the Administrative Procedure Law, courts are required to "accept suits brought by citizens, legal persons or other organizations against any of the specific administrative acts

${ }^{107}$ Id., p. 123 [citing Fei-Ling Wang, (stating that "raising the purchasing power of the rural Chinese majority would probably provide the Chinese economy with a great push in the years ahead")].

${ }^{108}$ Id., p. 138.

${ }^{109}$ Ibid.

${ }^{110}$ Ibid.

${ }^{111}$ Administrative Procedure Law of the People's Republic of China, (enacted in 4 April 1989, and in force on 1 October 1990).

${ }^{112}$ Id., Article 1.

${ }^{113}$ Id.. Article 3.

${ }^{114}$ Id., Articles 4 and 5. 
embodied in Article 1 which include confiscation of property, freezing of property, infringement of rights of the person or property, and other rights. ${ }^{115}$

Series of laws have also been promulgated that incorporate elements of administrative law, such as the Legislative Law (2000), Administrative Supervision Law (1997), Administrative Punishment Law (1996), State Liability Law of the People's Republic of China (1994) and others. The lessons that can be drawn in this regard relate to the specificity of the functions of administrative authorities, the procedures of redress and judicial review. There is, however, criticism regarding the level of the implementation of these laws.

As Liu Jianlong observes, "the effectiveness of the law in controlling public powers" is modest in China and he attributes this problem to three factors: the vulnerability of courts to interference from administrative organs, "the mechanical dogmatic approach adopted by most judges", and the need to update some of the provisions of the 1989 Administrative Procedure Law. ${ }^{116}$ Jianlong states that the 1982 Constitution "and the three procedural laws have clearly specified that the courts exercise their trial powers independent of any interference from administrative organs, social organizations and

${ }^{115}$ Id., Article 1. The rights protected are the following:

(1) an administrative sanction, such as detention, fine, rescission of a license or permit, order to suspend production or business or confiscation of property, which one refuses to accept;

(2) a compulsory administrative measure, such as restricting freedom of the person or the sealing up, seizing or freezing of property, which one refuses to accept;

(3) infringement upon one's managerial decision-making powers, which is considered to have been perpetrated by an administrative organ;

(4) refusal by an administrative organ to issue a permit or license, which one considers oneself legally qualified to apply for, or its failure to respond to the application;

(5) refusal by an administrative organ to perform its statutory duty of protecting one's rights of the person and of property, as one has applied for, or its failure to respond to the application;

(6) cases where an administrative organ is considered to have failed to issue a pension according to law;

(7) cases where an administrative organ is considered to have illegally demanded the performance of duties; and

(8) cases where an administrative organ is considered to have infringed upon other rights of the person and of property.

Apart from the provisions set forth in the preceding paragraphs, the people's courts shall accept other administrative suits which may be brought in accordance with the provisions of relevant laws and regulations.

${ }^{116}$ Liu Jianlong (2011), 'Administrative Litigation in China: Parties and Their Rights and Obligations', NUJS Law Review, Volume 4, April-June 2011, p. 229. 
individuals". ${ }^{117} \mathrm{He}$ thus underlines the need to guarantee the financial and personal independence of the courts and the judges and improve the education level of judges. ${ }^{118}$

\section{Land Rights in Singapore and Entrepreneur Perceptions}

\subsection{Land rights in Singapore}

The ideology of People's Action Party (PAP) as of the early 1960s included social engineering, economic growth, modesty in lifestyle, Asian Values, and meritocracy. ${ }^{119}$ As an island city state, Singapore devised a land law regime that could enable the state to have a wide policy space in the construction of residential, office and commercial premises. Its housing project targeted at its whole population. Over 80 percent of the population now lives in self-owned apartments. "The government also allows citizens to borrow from the centralized pension system for home purchase, another incentive that has helped push the percentage of owner-occupiers to such high levels". ${ }^{120}$

The legal framework on Singapore's real property traces its roots to English common law. All land in Singapore belongs to the state, and there is a distinction in land titles, namely freehold and leasehold estates. The power of the state in freehold estate is limited to the exercise of "police powers and the right of eminent domain". "Freehold estates form a small minority of private land holdings in Singapore and are no longer granted by the government" while "[1] easehold is the primary form of land ownership in the country. Leasehold estates are granted by the government, typically for 99-year terms. The 1992 State Lands Act made the 99-year term the standard except for rare exceptions. $^{122}$

The general categories of the freehold and lease estates include various specific types of titles within the framework of the principle that land belongs to the state and may be granted to individuals or legal persons. "The grantees do

\footnotetext{
${ }^{117}$ Ibid.

${ }^{118}$ Ibid.

${ }^{119}$ David E. Anderson (2002), "Land Rights and Economic Opportunities, an exploratory comparison of Singapore and Taiwan" [in Douglas, I., Huang, S. L. (Editors) Urbanization, East Asia and Habitat II, Taipei, TW: CIER Press, p. 171]

${ }^{120}$ Belina Yuen (2007), "Squatters No More: Singapore Social Housing", Global Urban Development Magazene, Vol. 3. Issue 1, November 2007, Available at $<$ http://www.globalurban.org/GUDMag07Vol3Iss1/Yuen.htm>, Accessed 04 August 2013.

${ }^{121}$ National Association of Realtors $<\mathrm{http}$ ://www.realtor.org/intlprof.nsf/all/singapore?OpenDocument\&Print=Yes $>$, accessed 01 August 2013.

${ }^{122}$ Ibid.
} 
not really own the physical land itself but periods of time over the land during which they can exercise their rights of ownership. These time periods are called 'estates'." "23 Singapore's land law recognizes four kinds of estate in land, namely "the freehold fee simple estate, the freehold life estate, the estate in perpetuity created by the State Lands Act, and the leasehold estate". ${ }^{124}$

Even though all land belongs to the State, it does not mean that there is no private property in Singapore. The individuals or the institutions that are granted estates of land by the State are true 'owners' and are entitled to certain rights over the land. The commonly accepted rights associated with the ownership of an estate in land are the rights to possess and to exclude all others from accessing the land, the right to use and enjoy it in the manner the owner likes subject to the existing rules, and the right to alienate it. ${ }^{125}$

Distinction is made between "two categories of land in Singapore: private land, enjoyed by the individuals and corporations that are granted estates in land by the State, and State land". ${ }^{126}$ A person who owns the freehold fee simple estate "owns the property indefinitely, without the need to pay any rent, and upon his death, the property passes onto his successors. The second freehold estate is the life estate, which is much rarer, and confers ownership for the duration of the person's lifetime". ${ }^{127}$ Leasehold estates, as stated above are usually granted for 99 year leases. "An estate in perpetuity is an interest in land, created by a grant of land to an individual by the State in perpetuity, subject to terms and conditions agreed upon by the two parties. Such an interest may also be governed by the State Lands Act". ${ }^{28}$

\subsection{Entrepreneur perceptions about Singapore's institutions}

Singapore is well known for its rate of development, low unemployment rates, nearly corruption-free government, its attraction to Foreign Direct Investment and foreign workforce. It is "a small island city-state with a total land area of 640 square kilometers" and has gone through challenges when it obtained its internal self-government (1959), "joined the then newly formed Federation of Malaysia in 1963" from which it withdrew and became an independent republic

${ }^{123}$ Soicher Mihaela Ecaterina (2004), The Applicability in Singapore of the Principle of Reasonable Access to Land Open for Public Use (LL.M Thesis, University of Singapore), p. 1.

${ }^{124}$ Ibid.

125 Ibid.

${ }^{126}$ Ibid.

${ }^{127}<$ http://singaporelegaladvice.com/types-of-property-and-home-ownership-insingapore/>, last accessed: 04 August 2013.

${ }^{128}$ Ibid. 
in 1965. ${ }^{129}$ There were various problems encountered by the government of Singapore upon independence which include rapid population growth, housing shortages and unemployment. ${ }^{130}$ These problems are events of the past, because "Singapore has become a model for economic development" and there is virtually no unemployment in the country. ${ }^{131}$ "The national savings rate is 51 percent while the home ownership rate is 92 percent". ${ }^{132}$

Surveys were conducted about the institutional settings which included private property rights in Hong Kong and Singapore before Hong Kong was united to China. "The surveys of Hong Kong and Singapore were part of an attempt to gain a world-wide private sector assessment of institutional quality... in June 1997, i.e., just before the handover of Hong Kong to China". ${ }^{133}$ The themes of the survey (on entrepreneur perceptions) were predictability of rule making, perception of political instability, security of persons and property, predictability of law enforcement and corruption, and expectations of future developments in these areas of private sector concerns. ${ }^{134}$

${ }^{129}$ Sock-Yong Phang (1996), "Economic Development and the Distribution of Land Rents in Singapore: A Georgist Implementation", American Journal of Economics and Sociology, Vol. 55, No. 4 (Oct., 1996), p. 490.

${ }^{130}$ Ibid.

${ }^{131}$ Ibid.

${ }^{132}$ Ibid.

${ }^{133}$ Beatrice Weder and Aymo Brunetti (2000), "Another Tale of Two Cities: A Note on Institutions in Hong Kong and Singapore", Journal of Institutional and Theoretical Economics (JITE) / Zeitschrift für diegesamte Staatswissenschaft, Vol. 156, No. 2 (June 2000), p. 317.

134 "Predictability of rule making: ... [1] the extent to which entrepreneurs have to cope with unexpected changes in rules and policies; [2] whether they expect their governments to adhere to announced policies; ... [3] the degree to which entrepreneurs are informed about important changes in rules; [4. Whether they] can voice concerns when planned changes affect their business; [5. whether] ... entrepreneurs have to cope with unpredictable retrospective changes in laws and regulations.

Perception of political instability: ... whether government changes (constitutional and unconstitutional) are perceived to be accompanied by far-reaching policy surprises which could have serious effects on the private sec-tor.

Security of persons and property: ... [1] whether entrepreneurs feel confident that the authorities would protect them and their property from criminal actions, and [2] whether theft and crime represent serious problems for business operations.

Predictability of law enforcement and corruption: ... [1] the uncertainty arising from arbitrary enforcement of rules by the judiciary and whether such unpredictability presents a problem for doing business. [2] whether it is common for private entrepreneurs to have to pay some irregular additional payments to get things done". 
The results of the survey showed that "entrepreneurs in both Singapore and Hong Kong gave top marks to the institutional infrastructure" with ratings "very similar for both city-states and in most cases they were clearly higher than for all other countries surveyed". ${ }^{135}$ Hong Kong's score regarding perception of changes in government was significantly higher than Singapore's owing to "the fairly centralized political system of Singapore"136 which caused higher perception in change of laws. However, this perception about Singapore was not related to entrepreneurs' perception of "unconstitutional government changes accompanied by far-reaching policy surprises". ${ }^{137}$

The rating for Singapore with regard to predictability of rule making was "more favorable than for an average of OECD countries" as "about $90 \%$ of responding entrepreneurs in both Hong Kong and Singapore said that in general they expected government to stick to announced policies". ${ }^{138}$ The number of entrepreneurs who "feared retrospective changes in regulation which could be important for their business" was very few, while "by comparison, in Africa this fear was expressed by over $50 \%$ of entrepreneurs". ${ }^{139}$

Entrepreneurs in both Hong Kong and Singapore agreed that "property rights security is not a problem" and "they felt completely confident that the state authorities would protect their person and property from criminal actions and that theft and crime were absolutely no problem for their business". ${ }^{140}$ With regard to the reliability of the judiciary "over $80 \%$ of entrepreneurs responded positively, compared with only $60 \%$ in the average of the OECD, and only $20 \%$ in the average of less developed countries". ${ }^{141}$ All entrepreneurs responded very positively regarding the absence of corruption. "Overall, the private sector surveys suggest that the quality of institutions in Hong Kong and Singapore was extraordinarily benign". 14

\section{Conclusion}

Comparative experience of other countries can inform Ethiopia's pursuits of addressing the challenges in the legislative, administrative and judicial

The final question ... asks entrepreneurs about their expectations of future developments in the four main areas discussed above." Weder and Brunetti, Ibid. P. 318.

\footnotetext{
${ }^{135}$ Id., p. 319.

${ }^{136}$ Id., p. 321.

${ }^{137}$ Id., p. 321.

${ }^{138}$ Id.. p. 319.

${ }^{139}$ Id., p. Ibid.

${ }^{140}$ Id., p. 321.

${ }^{141}$ Ibid.

${ }^{142}$ Ibid.
} 
protection of property rights. The denial of economic value to land use rights in any country that pledges to pursue developmental state economic policies is incompatible with the land policies and laws pursued by the developmental states of the 1960s such as South Korea and Taiwan which offer good examples regarding the role of the state at the initial phases of industrial kick-off. Moreover, the experience of Singapore that has a legal regime based on state ownership of land shows that security and tenure in land use rights can be put in place even under state ownership. A Legal regime that restricts the scope of land use rights can also take lessons from the steady reforms that are underway to widen the scope of China's land use rights regime even if China still espouses socialism blended with market-led economic policies.

There are lessons that can be drawn from the legal regimes of these countries in relation with the various proclamations in Ethiopia's property rights regime that deal with the scope, tenure and security of urban and rural land use rights. One of the major avenues that benefit from the experience of developmental states is expropriation. Although there can be various definitions of expropriation, they share common characteristics in that the "expropriation should be for 'public use', carried out on behalf of the public", and it should involve just compensation ${ }^{143}$ which should not be confined to the value of the fixtures and houses on the land. Generally, "compensation should be for loss of any land, buildings, other improvements" or for their reduction of value "as a result of the acquisition, and for any disturbances and other losses to the livelihoods of the owners or occupants caused by the acquisition and dispossession (FAO 2008)". ${ }^{144}$

As the purpose of this article is to highlight some country experience in the legal regimes of four countries, the definition of public purpose, expropriation and compensation under Ethiopian law is beyond the scope of our discussion. What can be said in the context of this article is that the economic value to land use rights, definition of 'public purpose' and the amount of compensation upon expropriation need careful consideration. First, the extent to which the definition of "public purpose ${ }^{145}$ is wider than the one that was used in the

${ }^{143}$ Yin Lei (2010), Developing Online Participatory Model (OPM) for Land Expropriation in China (MSc Thesis, International Institute for Geo-Information Science and Earth Observation, Enshede, the Netherlands), p. 2.

144 Id., p. 18.

145 According to Article 2(5) of the Expropriation of Land Holdings for Public Purposes and Payment of Compensation Proclamation No. 455/2005, 'public purpose' "means the use of land defined as such by the decision of the appropriate body in conformity with urban structure plan or development plan in order to ensure the interest of the peoples to acquire direct or indirect benefits from the use of the land and to consolidate sustainable socio-economic development." 
developmental state policies of the countries considered in this article, and secondly, the issue whether economic value to land use rights is denied in Ethiopia thereby lowering the amount of compensation (upon land expropriation) can be informed by the lessons that can be drawn from the country experience discussed in the preceding sections.

As the experience of South Korea and Taiwan indicates, developmental states have features and policies which enhance economic development, and it is these factors that determine the classification of a state into one of the stations between predatory and developmental statehood. The land laws of developmental states clearly pursue the principle of equitable redistribution without denying private rights on land. China pursues socialism with 'Chinese characteristics' and yet it clearly recognizes the urban landholder as "the owner of the right to the use of land for construction". The fact that China is in the course of further reforms toward indefinite terms in use rights and other issues including compensation will further enhance the tenure and security of property rights.

And finally, the lessons from Singapore's land regime indicate that individuals and companies can own estates, i.e. the years during which one can have use rights even if the state has bare ownership. The duration of the estates according to Singapore's land law may be for an indefinite duration, 99 years, or lesser number of years based on the category of the estates to which a person is entitled to. The lessons that can be drawn from Singapore also relate to the level of institutional competence and integrity.

The land reform of developmental states (such as South Korea and Taiwan in the 1950s and 1960s) has indeed enhanced agricultural productivity and saving which ultimately facilitated industrialization. Moreover, the land laws in Singapore and the steady land use right reforms in China prove that private ownership of land use rights can co-exist with public ownership of land. The comparative experience discussed in this article thus shows that private ownership of land use rights and public ownership of land are not exclusive (either/or) opposites but aspects of land rights that can co-exist in harmony within a holistic spectrum of property rights. 